\title{
FKBP1A Gene
}

National Cancer Institute

\section{Source}

National Cancer Institute. FKBP1A Gene. NCI Thesaurus. Code C102483.

This gene is involved in both signaling and protein folding. 